\title{
Polyculture of crayfish (Procambarus acanthophorus) and Nile tilapia (Oreochromis niloticus) as a strategy for sustainable water use
}

\author{
Policultivo del acocil (Procambarus acanthophorus)y y tilapia del Nilo (Oreochromis niloticus) como estrategia de uso \\ sustentable del agua
}

\author{
Martha P. Hernández-Vergara, Selene B. Cruz-Ordóñez, Carlos I. Pérez-Rostro and I. Alejandro Pérez-Legaspi
}

¿Laboratorio de Nutrición Acuícola, División de Estudios de Posgrado e Investigación, Instituto Tecnológico de Boca del Río (ITBOCA), TecNM. Km. 12 Carr. VeracruzCórdoba. Boca del Río, Veracruz, 94290. México e-mail: mphv1@yahoo.com.mx

Recibido: 02 de julio de 2015.

Aceptado: 20 de diciembre de 2017.

Hernández-Vergara M. P., S. B. Cruz-Ordóñez, C. I. Pérez-Rostro and I. A. Pérez-Legaspi. 2018. Polyculture of crayfish (Procambarus acanthophorus) and Nile tilapia (Oreochromis niloticus) as a strategy for sustainable water use. Hidrobiológica 28 (1): 11-15. D0I: 10.24275/uam/izt/dcbs/hidro/2018v28n1/HernandezV

\begin{abstract}
Background. The crayfish Procambarus acanthophorus has a high potential for cultivation; however, it is necessary to evaluate its performance in polyculture with tilapia as a strategy for sustainable production in the rural sector where resources are limited. Goals. Assess the effect of polyculture of the crayfish and tilapia by measuring survival and growth. Methods. Three methods of cultivation with three replicates were evaluated: T1) crayfish monoculture, T2) polyculture crayfish/tilapia and T3) tilapia monoculture. Nine high-density polyethylene tanks ( $3 \mathrm{~m}$ diameter $\times 1.2 \mathrm{~m}$ deep) were used during the trial. The tilapia were fed commercial feed, $32 / 5 \%$ protein / lipids, while the crayfish were given commercial shrimp feed with $35 / 7 \%$ protein / lipids. The productive efficiency of mono- and biculture was determined based on survival feeding efficiency and growth performance. Results. Contrary to what was expected, interspecific competition, space, food availability, and weight gain of crayfish were similar in all treatments, whereas survival was influenced by the treatment, particularly during polyculture, where it was observed that tilapia affected the survival of crayfish. Unlike crayfish, tilapia maintained similar growth and survival in all treatments. Conclusions. The results indicate that polyculture of crayfish/tilapia in a recirculation system is possible and promotes the use of the water column. However, it is necessary to consider the antagonistic effect between species.
\end{abstract}

Keywords: antagonistic behavior, crayfish, polyculture, sustainable aquaculture

\section{RESUMEN}

Antecedentes. Los cangrejos de río Procambarus acanthophorus, tiene un alto potencial de cultivo; sin embargo, es necesario evaluar su desempeño en policultivo con tilapia como estrategia de producción sustentable para el sector rural, donde los recursos son limitados. Objetivos. Evaluar el efecto del policultivo del acocil y la tilapia en la supervivencia y el crecimiento. Métodos. Se evaluaron tres esquemas de cultivo con tres réplicas: T1) monocultivo de acocil, T2) policultivo acocil/; T3) monocultivo de tilapia. Nueve tanques de polietileno de alta densidad ( $3 \mathrm{~m}$ diámetro $\times 1.2 \mathrm{~m}$ profundidad) fueron usados durante el estudio. Las tilapias se alimentaron con alimento comercial con 32/5\% proteína/lípidos, mientras que a los acociles se les dio alimento comercial de camarón con 35/7\% proteína/lípidos. La eficiencia productiva en el mono- y bicultivo se determinó en base a la supervivencia, eficiencia alimenticia y crecimiento. Resultados. Contrario a lo esperado en relación con la competencia interespecífica, espacio y disponibilidad de alimento, fue similar el peso ganado de los acociles en todos los tratamientos, mientras que su supervivencia estuvo influenciada por los tratamientos, particularmente en el policultivo, en donde se observó que la tilapia afectó la supervivencia de los acociles. A diferencia de los acociles, las tilapias presentaron una supervivencia y crecimiento similar en todos los tratamientos. Conclusiones. Los resultados indican que es posible realizar el policultivo de acocil/tilapia en un sistema de recirculación, lo que promueve el aprovechamiento de la columna de agua, considerando sin embargo el efecto antagónico entre especies.

Palabras clave: acocil, acuacultura sustentable, comportamiento antagónico policultivo 


\section{INTRODUCTION}

Mexico has a wide diversity of crayfish (family Cambaridae), including 42 species of the Procambarus genus, 10 in the Cambarellus genus, and one in the Orconectes genus (Gutiérrez-Yurrita, 2004). Cambarids are found in habitats associated with the roots of riparian vegetation at the surface of the bottom sediment where they form galleries. Crayfish are omnivorous and are key energy transformers in the food chain of freshwater systems, regulating river productivity. Cambarids are found in southern Canada, along the east and west coast lowlands of the United States, where they are abundant in the southeastern region. In Mexico, they are found on the Pacific coast and Gulf of Mexico, especially in the central part of the state of Veracruz (López, 2008) as well as in streams of the Lerma-Chapala river basin system (Arredondo-Figueroa et al., 2011). Consumption of crayfish is important in rural areas of the states of Tlaxcala, Hidalgo, Mexico, Michoacán, Puebla, and Veracruz (since the pre-Hispanic age). In contrast, in Europe and the United States, crayfish is considered a luxury food (Latournerié et al., 2006).

Despite the abundance of crayfish worldwide, less than a dozen species are cultivated worldwide and only two species are important in commercial fisheries (Huner, 1994). Like tilapia, some crayfish are widely used in aquaculture systems because they are prolific and easily maintained under controlled conditions (Cervantes-Santiago et al., 2007). This makes them less vulnerable to drastic environmental changes and resistant to stress from handling and poor water quality. Compared to brackish or marine water crustaceans, freshwater crayfish require less investment in construction and maintenance of cultivation systems and can produce acceptable profits for farmers in rural areas where high-quality, low-cost protein is always in low supply (Wickins \& Lee, 2002; Anderson, 2007). Therefore, it is important to conduct studies about Procambarus acanthophorus (Villalobos, 1948) in captivity. They could be a good option for polyculture considering that they exhibit low aggressiveness and are tolerant to high stocking densities (100 ind. $\left.\mathrm{m}^{-2}\right)$ (Cruz, 2009). Furthermore, polyculture increases economic benefits because farmers have the option of selling the most valuable commercial species and keeping smaller or less valuable ones (usually the native species) for family consumption (Milstein et al., 2009). Additionally, polyculture is a sustainable, semi-intensive, aquaculture technology. Culture is optimized by manipulating the combinations of fish species stocked, considering the ecological effects produced by deep bottom feeders on the pond and filter feeders in the water column (Wahab et al., 2011). Brummett and Alon (1994) reported positive results with the culture of red claw crayfish Cherax quadricarinatus (von Martens 1868) and Nile tilapia Oreochromis niloticus (Linnaeus 1757) in earthen ponds. However, Rouse \& Kahn (1998) reported competition for feed and space between the same species with negative effects on survival of crayfish. Recirculation systems are considered a better alternative in comparison to earthen ponds because the water quality and feed supply can be controlled and shelters can be provided to prevent territorial competition among the organisms. This allows the species to grow properly and survive (Karplus et al., 2001). Cohen et al. (1983) found that the presence of filter-feeding fish (such as Nile tilapia) improve water quality for prawn production. In this sense, the aim of this study was to determine what type of interaction between the crayfish $P$. acanthophorus and the Nile tilapia 0 . niloticus cultivated together in tanks would be synergistic or antagonistic based on growth and survival.

\section{MATERIALS AND METHODS}

Experimental system. Juvenile Procambarus acanthophorus were obtained from broodstock in the Native Crustaceans Laboratory of the ITBOCA, and tilapia Oreochromis niloticus fingerlings were provided by a local commercial farm. Nine high-density polyethylene tanks ( $3 \mathrm{~m}$ diam $\times 1.2 \mathrm{~m}$ deep) were filled to $1 \mathrm{~m}$ of the water column and constantly aerated using a $2.5 \mathrm{hp}$ regenerative blower Sweetwater $₫$. Polyvinyl chloride (PVC) tubes $(1.9 \mathrm{~cm}$ diam $\times 5 \mathrm{~cm})$ were spread in the pond bottom as shelters for the crayfish at a 1:1 ratio. A shade cloth shelter ( $90 \%$ reduction of sunlight) covered the tanks to maintain the temperature and to prevent predation from wild animals.

Experimental design. A completely random design in triplicate was used to test for the advantages of polyculture. Treatment 1 (T1) was a monoculture of crayfish (initial weight $=1.02 \pm 0.2 \mathrm{~g}$ ) stocked at 30 juveniles crayfish $\mathrm{m}^{-2}$. Treatment 2 (T2) was a polyculture of crayfish (initial weight $=1.02 \pm 0.2 \mathrm{~g}$ ) stocked at 30 crayfish $\mathrm{m}^{-2}$ with Nile tilapia fingerlings (initial weight $=2.99 \pm 0.1 \mathrm{~g}$ ) stocked at 20 fish $\mathrm{m}^{-3}$ including PVC tubes as shelters on the bottom of the pond. Treatment 3 (T3) was a monoculture of Nile tilapia fingerlings (initial weight $=3.45$ $\pm 0.6 \mathrm{~g}$ ) stocked at $20 \mathrm{fish}^{-3}$. All fish and crayfish were stocked on the same day.

Feeding and measurement of organisms. To prevent inter-species competition, two commercial diets (Pedregal Silver Cup, Toluca Mex.) were provided: tilapia diet containing $32 / 5 \%$ protein/lipid and shrimp feed containing $35 / 7 \%$ protein/lipid. The feed was provided three times a day $(0900,1400$, and 1800 h). Tilapias were fed first and crayfish were fed 30 min later (Meyer-Burgdorff et al., 1989). Diets were provided at $10 \%$ of total weight of each species at the beginning of the study period and then adjusted upward, based on consumption and weight gain. Body weight of the organisms was recorded at the beginning of the experiment and every 15 days during the 7-week trial. For each measurement, 30 crayfish and 30 fish were taken from every tank (90 per treatment), excess water was removed, and the subjects were weighed (King, 1994) with an electronic balance $( \pm 0.01 \mathrm{~g}$; Scout Pro CS200, Ohaus, Parsippany, NJ, USA). Length was measured with a 30-cm ichthyometer.

Environmental parameters. Water temperature was measured daily with a mercury thermometer and $\mathrm{pH}$ measured with a $\mathrm{pH}$ meter (Hanna Instruments, Woonsocket, RI, USA). Each week the following were recorded (mg L-1): ammonium $\left(\mathrm{NH}_{4}\right)$, dissolved oxygen $\left(\mathrm{O}_{2}\right)$, hardness $(\mathrm{KOH}), \mathrm{N}$-nitrite $\left(\mathrm{NO}_{2}\right)$, N-nitrate $\left(\mathrm{NO}_{3}\right)$, and phosphates $\left(\mathrm{PO}_{4}\right)$ using colorimetric tests (Nutrafin, Hagen, Montreal, QC).

Response parameters. Productive efficiency of mono- and biculture was determined with a basis on survival feeding efficiency and growth performance, using the following equations (Hernández-Vergara et al., 2003):

Survival: $S(\%)=100[(\mathrm{FC}-\mathrm{IC})] /$ IC

where $\mathrm{FC}$ is the final count and IC is the initial count.

Specific growth ratio: SGR $\left(\%\right.$ day $\left.^{-1}\right)=100\left(\log _{n} F W-\log _{n} I W\right) \times T$

where FW is the final weight, IW is the initial weight, and T is time.

Individual weight gain: IWG $(\mathrm{g})=100(\mathrm{FW} / \mathrm{IW}) \times \mathrm{IW}$

Feed conversion ratio: $F C R=F I / W G$

where $\mathrm{Fl}$ is feed intake $(\mathrm{g})$ and $\mathrm{WG}$ is weight gain $(\mathrm{g})$. 
Results were compared using one-way analysis of variance (ANOVA) and considered significant at $p \leq 0.05$ after normality and homoscedasticity tests. Duncan's multiple range test was used to identify statistically significant differences among treatment means. All analyses were done with Statistica 7.0 software (StatSoft, Tulsa, OK, USA). When necessary, data were arcsine transformed prior to statistical analysis (Zar, 1999).

\section{RESULTS}

Water quality parameters during the study were within acceptable ranges for tilapia and crayfish; therefore, these parameters did not affect the results (Cervantes et al., 2007). One exception was the concentration of dissolved oxygen, which remained below recommended levels for these species (recommended: $>4 \mathrm{mg} \mathrm{L}^{-1}$ ). None of the fish and crayfish exhibited stress or anoxia, which we do not consider to affect growth and survival. Temperature increased during the experiment. Average temperature in February was $23.4 \pm 1.5^{\circ} \mathrm{C}$ increasing in April to $28.2 \pm 1.2^{\circ} \mathrm{C}$ (Table 1$)$.

No differences in the variables for each species were identified among replicates; therefore, the results were treated as a single group in later analyses. Survival of the T2 crayfish was significantly lower (34.7\%) compared to survival of the $\mathrm{T} 1$ crayfish $(72 \%)$. In contrast, tilapia in T2 and T3 trials showed similar survival (>95\%) and growth (83-86 g) with no apparent effect from the crayfish (Table 2).

Lower crayfish survival in the T2 trial had no apparent effect on growth as might be expected from the presence of tilapia because IWG and WF in T2 (0.033 $\pm 0 \mathrm{~g} ; 3.9 \pm 0.3 \mathrm{~g}$, respectively) were significantly lower than $\mathrm{T} 1$ (0.042 g; $4.8 \pm 0.4 \mathrm{~g}$, respectively). This is in contrast to the T2 crayfish where random distribution of shelters and presence of tilapia prevented free access to food.

\section{DISCUSSION}

Based on previous laboratory studies, it can be stated that the environmental and water quality conditions required by crayfish and tilapias are very similar, which facilitates their combined culture. Water quality during the trial was tolerated by tilapia and crayfish (Cohen et al., 1983, Holdich 2002, El-Sayed, 2006). Therefore, we concluded that the differences observed during the study were due only to the treatments under evaluation.

Mexican crayfish have a high potential for cultivation and are widely tolerant to environmental conditions; this makes them ideal for commercial cultivation, but only a few crayfish are used for this purpose in the country (Hernández-Vergara \& Pérez-Rostro, 2012). In contrast, tilapia is the second most produced species in aquaculture production in the world (FA0, 2005-2017), due to its capacity to adapt to different conditions and environments, allowing them to grow both individually and with other species, including some crustaceans.

During cultivation with tilapia, the bottom of the pond is usually "free" until the tilapia begin to mature sexually and look for areas to reproduce.

Furthermore, the crayfish $P$. acanthophorus, like other decapods crustaceans, has some biological advantages for aquaculture facilities: adaptation to conditions of captivity and handling, acceptance of feed from different origins (even feed diets with high vegetal protein levels), and spawning with high survival rates $(75 \%)$ (Hernández-Vergara \& Pérez-Rostro, 2012). The physiological characteristics of crayfish allow them to adapt to extreme climatic variations, diversifying their potential habitat, ensuring reproduction, and contributing to progeny survival under adverse conditions (Gutierrez-Yurrita, 1994; Rodríguez-Almazán \& Mendoza-Alfaro, 1999). In spite of the biological and aquaculture potential of crayfish, research on the cultivation technology is recent. This study is the first report of the polyculture of crayfish Procambarus acanthophorus with Nile tilapia Oreochromis niloticus with interesting results on the feasibility of combined culture and the fact that crayfish usually remain at the bottom of the ponds, where they take advantage of remaining food not consumed by other species or organic material in decomposition (Hernández-Vergara \& Pérez Rostro, 2010).

Table 1. Average water quality parameters during polyculture of crayfish Procambarus acanthophorus (Villalobos, 1948) and Nile tilapia Oreochromis niloticus (Linnaeus 1757) in a recirculating water system.

\begin{tabular}{|c|c|}
\hline Parameter & Average \pm SD \\
\hline Temperature $\left({ }^{\circ} \mathrm{C}\right)$ & $25.20 \pm 2.21$ \\
\hline $\mathrm{pH}$ & $8.20 \pm 0.15$ \\
\hline $\mathrm{O}_{2}\left(\mathrm{mg} \mathrm{L}^{-1}\right)$ & $3.83 \pm 0.87$ \\
\hline $\mathrm{NH}_{3}\left(\mathrm{mg} \mathrm{L}^{-1}\right)$ & $0.13 \pm 0.08$ \\
\hline $\mathrm{N}-\mathrm{NO}_{3}\left(\mathrm{mg} \mathrm{L}^{-1}\right)$ & $25.30 \pm 12.30$ \\
\hline $\mathrm{N}-\mathrm{NO}_{2}\left(\mathrm{mg} \mathrm{L}^{-1}\right)$ & $0.40 \pm 0.54$ \\
\hline Hardness $\left(\mathrm{mg} \mathrm{L}^{-1}\right)$ & $298.00 \pm 18.50$ \\
\hline
\end{tabular}

$\mathrm{SD}$, standard deviation.

The results indicate that polyculture involving tilapia and crayfish did not affect species performance and they developed appropriately during the trials. Yet survival of the crayfish in polyculture was significantly lower than in the monoculture trials; however, it is possible to improve survival of crayfish when raised with tilapia using different strategies such as homogeneous distribution of shelters at the bottom of the tanks or ponds to avoid inter-specific competition for resources in the system (Gallardo-Colli et al. 2014).

Tilapia raised in tanks with crayfish was the main cause for lower growth performance in the $\mathrm{T} 2$ treatment, because all other variables were within the acceptable range for the crayfish. There may have been inter-species competition for space, feed, or even predation by the tilapia during molting of the crayfish or a response to a substantial difference in size. Size differences were not investigated because equal initial stocking sizes were used in all treatments $(1.03 \pm 0.77 \mathrm{~cm}$ for crayfish and $3.15 \pm 1.04 \mathrm{~cm}$ for tilapia). This larger size of tilapia provided a growth advantage over crayfish, which was clearly observed in T2. It is necessary to carry out further studies related to the effect of different types of shelters, disposition, and quantity to offer protection for the crayfish from the larger tilapia $(>90 \mathrm{~g}$ ) when they start showing breeding activities and the construction of nests at the bottom of the tanks and to determine the optimal time to harvest crayfish in a polyculture with tilapia. In this sense, Gallardo-Colli et al. (2014) evaluate the effect of bi-culture of tilapia/crayfish in an aquaponic system with a significantly higher survival rate $(59.6 \%)$ of crayfish with a homoge- 
Table 2. Growth and feeding efficiency in crayfish (T1) and tilapia (T3) under monoculture and crayfish (Procambarus acanthophorus (Villalobos, 1948)) - tilapia (Oreochromis niloticus (Linnaeus 1757)) polyculture (T2) in a recirculating water system

\begin{tabular}{|c|c|c|c|c|c|c|c|}
\hline \multicolumn{2}{|c|}{ Treatment } & $\mathrm{S}(\%)$ & IW (g) & FW (g) & IWG (g) & WG (\%) & SGR (\%) \\
\hline T1 & Crayfish & $72.0 \pm 12.7^{a}$ & $1.02 \pm 0.2^{\mathrm{a}}$ & $4.8 \pm 0.4^{\mathrm{a}}$ & $0.04 \pm 0.01^{\mathrm{a}}$ & $373.5 \pm 55^{\mathrm{a}}$ & $68.4 \pm 3.3^{a}$ \\
\hline \multirow[t]{2}{*}{ T2 } & Crayfish & $34.7 \pm 20.5^{b}$ & $1.04 \pm 0.1^{\mathrm{a}}$ & $3.9 \pm 0.3^{b}$ & $0.03 \pm 0.03^{b}$ & $282.6 \pm 73^{b}$ & $59.9 \pm 3.3^{b}$ \\
\hline & Tilapia & $98.7 \pm 5.3^{a}$ & $2.99 \pm 0.1^{\mathrm{a}}$ & $88.5 \pm 9.9^{a}$ & $0.95 \pm 0.10^{\mathrm{a}}$ & $2861.2 \pm 26^{a}$ & $194.2 \pm 5.3^{\mathrm{a}}$ \\
\hline T3 & Tilapia & $93.7 \pm 9.9^{a}$ & $3.45 \pm 0.6^{\mathrm{a}}$ & $84.3 \pm 10.7^{a}$ & $0.89 \pm 0.10^{\mathrm{a}}$ & $2344.9 \pm 71^{a}$ & $192.1 \pm 5.6^{a}$ \\
\hline
\end{tabular}

${ }^{1}$ Values in the same column with the same superscript are not statistically different $(p>0.05)$ for the same species.

Abbreviations: $S \%$ = survival rate; IW = initial weight; $F W=$ final weight; IWG = individual weight gain; $W G \%$ = percentage weight gain; $S G R=$ specific growth rate.

neous distribution of shelter in the bottom in a crayfish/shelter ratio of 1:1. Another strategy to improve survival could be to initially stock a small sized tilapia and crayfish and determinate the optimal final size for tilapia, in order to reduce inter-specific competition between species, which could improve the performance of the bottom species.

There are few studies aimed at determining the relevance of the bi-cultivation of tilapia (0. niloticus)-crayfish ( $P$. acanthophorus), so this study can be used as a technical reference for other species, such as the Australian crayfish Cherax quadricarinatus and other crabs. Nevertheless, most studies agree that polycultures increase profitability for producers and optimize the use of space and energy of cropping systems (Rouse \& Kahn, 1998; Auró et al. 2000; Karplus et al. 2001, Gallardo-Colli et al., 2014).

Previous reports on survival and growth of fish-crustacean polyculture differ widely, mostly concerning stocking densities, water quality, feed quality, and initial stocking sizes. Auró et al. (2000) raised common carp Cyprinus carpio (Linnaeus 1758) and crayfish Cambarellus montezumae (Saussure, 1857) in artificial ponds. The species co-existed and had enough food resources at densities up to 50 fish or crayfish $\mathrm{m}^{-3}$ under good water quality conditions. Karplus et al. (2001) reported that intensively farming $C$. quadricarinatus with tilapia over 133 days yielded normal survival for tilapia (90-95\%; 33 fish $\mathrm{m}^{-2}$ ) and slightly lower survival for crayfish $\left(60 \%\right.$; $10-20$ crayfish $\left.\mathrm{m}^{-2}\right)$. Rouse \& Kahn (1998) compared redclaw crayfish $C$. quadricarinatus-tilapia polyculture with monoculture of each species in an extensive system at low densities ( 0.5 crayfish $\mathrm{m}^{-2} ; 2$ tilapia $\left.\mathrm{m}^{-2}\right)$. Survival was $84-90 \%$ for tilapia and $19-23 \%$ for crayfish. Low survival of the crayfish was not the result of competition, but due to low dissolved oxygen near the bottom of the ponds in both treatments. Brummett and Alon (1994) also reported low survival of $C$. quadricarinatus grown with tilapia in earthen ponds at stocking densities of 1 tilapia $\mathrm{m}^{-2}$ and 2.5 crayfish $\mathrm{m}^{-2}$. Survival of tilapia was $76-95 \%$ and $20-45 \%$ for crayfish in all treatments, leading the authors to recommend tilapia monoculture. Barki et al. (2001) reported crayfish survival of $40-50 \%$ under polyculture and $72 \%$ under monoculture. They attribute the lower survival in polyculture to a 1:1 initial stocking ratio.

The crayfish $P$. acanthophorus has a high potential for aquaculture facilities. More studies are needed to determinate the best aquaculture conditions for commercial production. This species can adapt to high densities, handling, variable environmental conditions, and different artificial diets, although it does not reach market sizes that are as large as other crustaceans such as C. quadricarinatus (Cervantes, 2008; Cruz,
2009). Gutiérrez-Yurrita (2004) recommends new sustainable technologies to increase the yield of crayfish by cultivating native species for commercial exploitation and using them to recover exploited natural populations.

Raising crayfish in sustainable rural aquaculture farms is promising under monoculture and possibly under polyculture, but further research on optimal initial stocking size, stocking densities, shelter types, and quantities of crayfish is needed. Commercial exploitation of crayfish should be considered because they have high nutritional value, including vitamin $\mathrm{B}$, minerals ( $\mathrm{Na}, \mathrm{K}, \mathrm{Ca}$, and $\mathrm{Mg}$ ), and high concentrations of amino acids (leucine, isoleucine, glutamine, and asparagine), and organoleptic properties (Latournerié et al., 2006). Greater production of alternative protein sources using aquaculture in land rural areas is an important step towards increasing and diversifying our food supply. This becomes even more necessary when mixed cultivation uses local species, the local population already uses the aquatic species as food, and the second species has high commercial value in distant markets.

\section{ACKNOWLEDGEMENTS}

This research was supported by the Dirección General de Educación Superior Tecnológica (DGEST) project 1020-08P. SBC0 is a recipient of a Consejo Nacional en Ciencia y Tecnología fellowship (CONACyT 208558).

\section{REFERENCES}

Arredondo-Figueroa, J. L., A. Vásquez-González, L. G. Núñez.García, I. A. Barrlga-Sosa \& J. T. Ponce-Palafox. 2011. Aspectos reproductivos del acocil Cambarellus (Cambarellus) montezumae (Crustacea: Decápoda: Cambaridae) en condiciones controladas. Revista Mexicana de Biodiversidad 82:169-178. Available online at: http://www.revista. ib.unam.mx/index.php/bio/article/view/369/339

Anderson, J. L. 2007. Sustainable aquaculture: What does it mean and how do we get there. Chapter 2. In: Leung P.S., C.S. Lee and P. J. 0 'Bryen (Eds). Species and system selection for sustainable aquaculture. Blackwell Publishing, Ames, IA, USA, pp. 9-18.

Auró, A. A., C. M. Fragoso, C. L. Ocampo, L. H. Sumano \& S. D. Osorio. 2000. Evaluación del crecimiento de carpas (Cyprinus carpio var. rubrofuscus) y acociles (Cambarellus montezumae) en bicultivo, alimentados con ensilado de cerdaza empastillado, en un embalse 
artificial y en tanques de fibra de vidrio. México, Vol. 418/634. p. 5. Barki, A., N. Gur \& I. Karplus. 2001. Management of interspecific food competition in fish-crayfish communal culture: the effects of the spatial and temporal separation of feed. Aquaculture 201: 343354. DOI:10.1016/S0044-8486(01)00605-6

Brummett, R. E. \& N. C. Alon. 1994. Polyculture of Nile tilapia (Oreochromis niloticus) and Australian red claw crayfish (Cherax quadricarinatus) in earthen ponds. Aquaculture 122: 47-54. D0I:10.1016/00448486(94)90332-8

Cervantes, S. E. 2008. Relación proteína-lípidos y fuentes alternas de proteína en dietas para aprovechamiento sustentable del acocil Procambarus (Astrocambarus) acanthophorus. Tesis de Maestría en Ciencias (Acuacultura). Instituto Tecnológico de Boca del Río. Boca del Río, Veracruz, México. 93 p.

Cervantes-Santiago, E., M. P. Hernández-Vergara \& C. I. Pérez-Rostro. 2007. Sustitución de harina de pescado por harina de soya en dietas para crecimiento y supervivencia del acocil Procambarus (Austrocambarus) acanthophorus, en condiciones de laboratorio. In: LangoReynoso, F. \& M. R. Castañeda-Chávez (Eds.). Impulso Tecnológico. Aquamar Internacional Symposium Memorium. Special edition. Veracruz, México. pp. 107-114.

Cohen, D., Z. Ra'anan \& A. Barnes. 1983. Production of the freshwater prawn Macrobrachium rosenbergii in Israel 1. Integration into fish polyculture systems. Aquaculture 31:67-76. D0I:10.1016/00448486(83)90258-2

Cruz, 0. S. 2009. Cultivo piloto del acocil Procambarus (Astrocambarus) acanthophorus en bicultivo con la tilapia Oreochromis niloticus en un sistema de recirculación. Tesis de Maestría en Ciencias (Acuacultura). Instituto Tecnológico de Boca del Río, Veracruz, México. $77 \mathrm{p}$.

EL-SAYed, A. F. M. 2006. Tilapia culture. CABI Publishing. Department of Oceanography, Faculty of Science, Alexandria University. Alexandria, Egypt. pp. 139-145.

faO (Food and Agriculture Organization) 2005-2017. Cultured Aquatic Species Information Programme. Oreochromis niloticus. Programa de información de especies acuáticas. Texto de Rakocy, J. E. In: Departamento de Pesca y Acuicultura de la FAO [en línea]. Roma. Actualizado 18 February 2005. [Citado 25 July 2017]. Disponible en línea en: http://www.fao.org/fishery/culturedspecies/Oreochromis_niloticus/en (consultado el 25 de julio de 2017).

Gallardo-Colli A., M. P. Hernández-Vergara, C. I. Pérez-Rostro \& S. C. RamiREZ-GutiérREZ. 2014. Biculture of tilapia (Oreochromis niloticus) and crayfish (Procambarus acanthophorus) and production of green corn fodder (Zea mays) in an aquaponic system. Global Advanced Research Journal of Agricultural Science 3 (8): 233-244. Available online at: http://garj.org/garjas/index.htm

GutiérRez-YurRita, P. J. 2004. The use of the crayfish fauna in México: Past, present and future? Freshwater Crayfish 14: 30-36. Available online at: https://www.researchgate.net/publication/235987257

Hernández-Vergara, M. P. \& C. I. Pérez-Rostro. 2012. Advances in Domestication and Culture Techniques for Crayfish Procambarus acanthophorus. In: Muchilisin, Z. (Ed). Aquaculture. Intech. pp. 217-240.
Hernández-Vergara, M. P., D. B. Rouse, M. A. Olvera-Novoa \& D. A. Davis. 2003. Effect of dietary lipid level and source on growth and proximate composition of juvenile redclaw (Cherax quadricarinatus) reared under semi-intensive culture conditions. Aquaculture 223: 107-115. DOI:10.1016/S0044-8486(03)00135-2

HoLdich, D. M. 2002. Biology of Freshwater Crayfish. Blackwell Science, Osney Mead, Oxford. 720 p.

Huner, J. V. 1994. Freshwater Crayfish Aquaculture in North America, Europe, and Australia. Food Products Press. New York, USA.

Latournerié, J. R., Y. N. Osorio, R. J. Cárdenas \& J. Romero. 2006. Crecimiento, producción y eficiencias de energía de crías ce acocil Cambarellus montezumae (Saussure) alimentadas con detritus de Egeria Densa. REDVET. Revista Electrónica de Veterinaria VII (12). Available on line at: http://www.veterinaria.org/revistas/redvet

López, M. M. 2008. Sistemática de los acociles de México. In:Álvarez, F. \& A. G. A. Rodríguez (Eds.). Crustáceos de México, estado actual de su conocimiento. Universidad Autónoma de Nuevo León. México. pp 115-166.

Karplus, I., S. Harpaz, G. Hulata, R. Segev \& A. Barki. 2001. Culture of the Australian red-claw crayfish (Cherax quadricarinatus) in Israel-IV. Crayfish incorporation into intensive tilapia production units. Journal of Aquaculture-Bamidgeh 53 (1): 23-33. Available on line at: http://hdl.handle.net/10524/18971

KING, R. C. 1994. Growth and survival of red claw crayfish hatchlings (Cherax quadricarinatus, Von Martens) on the relative suitability of Cherax quadricarinatus and Cherax destructor for culture in Queensland. Aquaculture 122 (1): 75-80. D0l:10.1016/00448486(94)90335-2

Meyer-Burgdorff, K., M. F. Osman \& K. D. Gunter. 1989. Energy metabolism in Oreochromis niloticus. Aquaculture 79: 283-291. DOl:10.1016/0044-8486(89)90469-9

Mllstein, A., M. A. Wahab, A. KadiR, M. F., H. Sagor \& M. A. Islam. 2009. Effect of intervention in the water column and/or pond bottom through species composition on polycultures of large carps and small indigenous species. Aquaculture 286: 246-253. D0I:10.1016/j.aquaculture.2008.09.036

Rouse, D. B. \& B. M. KaHn 1998. Production of Australian red claw Cherax quadricarinatus in polyculture with Nile Tilapia Oreochromis niloticus. Journal of the World Aquaculture Society 29: 340-344. DOI:10.1111/j.1749-7345.1998.tb00656.x

WaHAB, M. A., A. KADIR,A. MILSTEIN \& M. KundA. 2011. Manipulation of species combination for enhancing fish production in polyculture systems involving major carps and small indigenous fish species. Aquaculture 321: 289-297. D0I:10.1016/j.aquaculture.2011.09.020

Wickins, J. F. \& D. 0. C. LeE. 2002. Candidates for cultivation. In: Crustacean Farming. Ranching and culture. Second Edition. Blackwell Science, Osney Mead, Oxford, UK, pp. 70-97.

ZAR, J. H., 1999. Statistical Analysis, $4^{\text {th }}$ ed. Prentice-Hall, New Jersey, USA. 